\title{
Sitokinin Organik: Pendampingan Kelompok Tani Sumber Urip-1 Desa Wonosari Kecamatan Poncokusumo Kabupaten Malang
}

\author{
${ }^{1}$ Moch. Agus Krisno Budiyanto, ${ }^{2}$ Tien Aminah, ${ }^{1}$ H. usamah, ${ }^{1}$ Fendy Hardian Permana, \\ ${ }^{1}$ Lud Waluyo \\ ${ }^{1}$ Prodi Pendidikan Biologi, FKIP Universitas Muhammadiyah Malang, Jl. Raya Tlogomas \\ 246 Malang, 65144 \\ ${ }^{2}$ ITSK RS dr. Soepraoen Malang; Jl. S. Supriadi No.22, Sukun, Kec. Sukun, Kota Malang, \\ Jawa Timur 65147 \\ Email Korespondensi: aguskrisno@umm.ac.id
}

\begin{tabular}{|c|c|}
\hline Article Info & bstract \\
\hline $\begin{array}{l}\text { Article History } \\
\text { Received: } 2020-10-22 \\
\text { Revised: } 2020-10-29 \\
\text { Published: } 2020-10-30\end{array}$ & \multirow[b]{2}{*}{$\begin{array}{l}\text { Organic Cytokinins: Mentoring to Sumber Urip-1 Farmer Group in } \\
\text { Wonosari Village, Poncokusumo District, Malang Regency. Partners in this } \\
\text { community service-Sumber Urip-1 Farmer Group, located in Poncokusumo } \\
\text { Village, Wonorejo District, Malang Regency, East Java Province-experienced } \\
\text { problems in the use of organic cytokines, namely the supply of organic } \\
\text { cytokinins sometimes not smooth and expensive, while in many partner areas } \\
\text { there is biological potential can be used as cytokinin organic matter. After } \\
\text { discussions/deliberations with partners, concrete issues and priorities that will } \\
\text { be addressed, namely 1) Partners have not mastered how to make organic } \\
\text { cytokinins based on local potential and 2) Partners have not mastered how to } \\
\text { use organic cytokinins according to local raw materials used in certain plants. } \\
\text { Solutions to be undertaken are 1) conducting training and mentoring of } \\
\text { organic cytokinins production and 2) training and mentoring of cytokinins } \\
\text { organic ToT (Training of Trainer) followed by 5 farmers from representatives } \\
\text { of Sumber Urip-1 Farmers Group. The results of further training and } \\
\text { assistance are disseminated to other farmer members. Through a series of } \\
\text { training activities, and assisting the manufacture and use of organic cytokinins } \\
\text { at Sumber Urip-1 Farmer Group Wonorejo Village, Poncokusumo Sub-district, } \\
\text { Malang Regency, the PPMI partners have mastered: 1) organic cytokinin } \\
\text { production methods and 2) Methods of cytokinins use. Organic cytokinin } \\
\text { products are branded "Sitonik-BP" (from Banana Veewil), and "Sitonik-JM" } \\
\text { (from corn). }\end{array}$} \\
\hline $\begin{array}{l}\text { Keywords } \\
\text { organic, } \\
\text { auxin, } \\
\text { gibberellins, } \\
\text { farmer groups, } \\
\text { local potency }\end{array}$ & \\
\hline Info & \\
\hline $\begin{array}{l}\text { Sejarah Artikel } \\
\text { Diterima: } 22-10-2020 \\
\text { Direvisi: } 29-10-2020 \\
\text { Dipublikasi: } 30-10-2020\end{array}$ & \multirow{2}{*}{$\begin{array}{l}\text { Mitra dalam pengabdian masyarakat ini Kelompok Tani Sumber Urip-1 yang } \\
\text { berlokasi di Desa Poncokusumo Kecamatan Wonorejo Kabupaten Malang } \\
\text { Provinsi Jawa Timur-mengalami kendala penggunaan sitokinin organik, yaitu } \\
\text { pasokan sitokinin organik terkadang tidak lancar dan harganya mahal } \\
\text { sedangkan di banyak daerah mitra terdapat potensi biologis yang dapat } \\
\text { digunakan sebagai bahan organik sitokinin. Setelah berdiskusi dengan mitra, } \\
\text { permasalahan kongkrit dan prioritas yang akan dibenahi, yaitu 1) Mitra belum } \\
\text { menguasai cara pembuatan sitokinin organik berbasis potensi lokal dan 2) } \\
\text { Mitra belum menguasai cara penggunaan sitokinin organik menurut bahan baku } \\
\text { lokal yang digunakan pada tanaman tertentu. Solusi yang akan dilakukan } \\
\text { adalah 1) melakukan pelatihan dan pendampingan produksi sitokinin organik } \\
\text { dan 2) pelatihan dan pendampingan sitokinin organik menggunakan ToT } \\
\text { Organik (Training of Trainer) yang diikuti oleh } 5 \text { orang petani dari perwakilan } \\
\text { Kelompok Tani Sumber Urip-1. Hasil pelatihan dan pendampingan selanjutnya } \\
\text { disebarluaskan kepada anggota petani lainnya. Melalui rangkaian kegiatan } \\
\text { pelatihan, dan pendampingan pembuatan dan pemanfaatan sitokinin organik di }\end{array}$} \\
\hline $\begin{array}{l}\text { Kata kunci } \\
\text { Kolaboratif } \\
\text { Komunitas belajar } \\
\text { LSLC }\end{array}$ & \\
\hline
\end{tabular}


Kelompok Tani Sumber Urip-1 Desa Wonorejo, Kecamatan Poncokusumo, Kabupaten Malang, mitra PPMI telah menguasai: 1) cara produksi auksin dan giberelin organik dan 2) Metode penggunaan sitokinin. Produk sitokinin organik diberi merk "Sitonik-BP" (dari Bonggol Pisang) dan "Sitonik-JM" (dari Jagung Muda)

Sitasi: Budiyanto K.A.M., Aminah T., H.usamah., Permana H.F., \& Waluyo L.(2020) Sitokinin Organik: Pendampingan Kelompok Tani Sumber Urip-1 Desa Wonosari Kecamatan Poncokusumo Kabupaten Malang. Sasambo: Jurnal Abdimas (Journal of Community Service). 2(3), 143-152. DOI 10.36312/sasambo.v2i3.309

\section{PENDAHULUAN}

Mitra dalam pendampingan ini adalah Kelompok Tani Sumber Urip-1 yang berada di Desa Wonorejo Kecamatan Poncokusumo Kabupaten Malang Propinsi Jawa Timur. Desa ini berada di timur laut Kota Malang dan berbatasan dengan Kabupaten Proboliggo (Lereng Tengger Gunung Bromo) yang menjadi salah satu sentra produksi pangan organik di Kabupaten Malang. Pada tahun 2015, Desa Wonorejo mempunyai jumlah penduduk 4.271 dengan jumlah laki-laki 1928 orang dan perempuan 2343 orang, sebagain besar bekerja sebagai petani dan peternak.

Terdapat 1.925 orang petani di Desa Wonorejo, sebagian besar (1254 orang, 65,14\%) menjadi petani atau terlibat dalam produksi pangan organik. Pangan organik yang diproduksi yang paling banyak adalah padi dan sayur. Para petani tersebut diorganisasikan dalam Kelompok Tani Sumber Urip-1. Kelompok Tani Sumber Urip-1 di Desa Wonorejo ini mempunyai eksistensi untuk berkembang di masa-masa mendatang (Budiyanto et al., 2020a). Hal ini dikarenakan kultur pertanian organik sudah lama dilakukan (Budiyanto et al., 2020b).

Budidaya pertanian organik telah berjalan dengan baik dan produktif di Desa Wonorejo. Produk organik yang paling banyak dihasilkan adalah padi, kol, gubis, tomat, kacang panjang, bayam, sawi, kacang panjang, cabai, dan bawang merah. Tantangan Kelompok Tani Sumber Urip-1 adalah cara memproduksi produk pangan organik $100 \%$. Selama ini produk pangan organik yang dihasilkannya belum mencapai organik $100 \%$ dikarenakan belum sepenuhnya menggunakan bahan-bahan organik dalam budidaya tanamannya. Petani organik telah menggunakan pupuk organik padat, pupuk cair organik, pupuk kotoran sapi, kompos, insektisida oganik, fungisida organik, dan herbisida organik tetapi petani masih menghadapi masalah penggunaan Sitokinin organik. Untuk itu Kelompok Tani Sumber Urip-1 Desa Wonorejo Kecamatan Poncokusumo Kabupaten Malang mempunyai keinginan memproduksi pangan organik 100\% melalui penggunaan sitokinin organik. Kelompok Tani Sumber Urip-1 mempunyai anggota aktif sebayak 673 petani yang sudah terbiasa terintroduksi dengan teknologi pertanian organik sehingga hal ini merupakan potensi SDM yang menjamin keterlaksanaan program pendampingan. Di sisi lain, potensi hayati yang melimpah di Desa Wonorejo sebagai bahan pembuatan sitokinin oranik (misal: bonggol pisang, jagung muda, tetes tebu, dan air kelapa) merupakan SDA yang juga menjamin keterlaksanaan program pendampingan. Pemdampingan yang akan dilakukan adalah 1) melakukan pelatihan dan pendampingan produksi sitokinin organik dan 2) pelatihan dan pendampingan sitokinin organik menggunakan ToT Organik (Training of Trainer) yang diikuti oleh 5 orang petani dari perwakilan Kelompok Tani Sumber Urip-1.

Pada abad ke-21 ini, tren pola gaya hidup sehat telah berhasil mendorong berkembangnya pertanian organik secara luas (Prihandarini, 2009). Pertanian organik merupakan salah satu alternatif menuju pembangunan pertanian yang ramah lingkungan dan berkelanjutan. Tujuan utama dari sistem pertanian organik adalah untuk menghasilkan produk bahan pangan yang aman bagi kesehatan produsen maupun konsumen dan tidak merusak lingkungan. Pengertian organik menurut FAO adalah "a holistic production management system which promotes and enhances agroecosistern health, including biodiversity, biological cycles, and soil biological activity" (suatu system managemen yang 
holistik yang mempromosikan dan meningkatkan pendekatan sistem pertanian berwawasan kesehatan lingkungan, termasuk biodiversitas, siklus biologi dan aktivitas biologi tanah. Pertanian organik merupakan suatu sistem pertanian berkelanjutan yang diakui oleh Komisi Eropa (European Commission) dan Agricultural Council (Aertsens et al., 2009; Jolly \& Norris, 1991).

Hasil penelitian sebelumnya telah diperoleh bahwa 1) persepsi masyarakat tentang pertanian hortikultura organik identik dengan pertanian sayuran dan buah yang tidak menggunakan pupuk buatan dan pestisida buatan (Budiyanto, 2007). Hasil penelitian Budiyanto (2012) tentang Tipologi Preferensi Konsumen terhadap Produk Pangan Organik di Kota Malang dapat dinyatakan bahwa: 1) Tipe pengambilan keputusan konsumen dalam memilih produk pertanian organik di Kota Malang adalah economic type (4\%), psychological type (13\%), consumer behaviour type (25\%), dan others type (58\%). Tipe lain-lain sebagian besar karena alasan kesehatan, dan 2) Faktor-faktor yang mempengaruhi konsumen dalam memilih produk pangan organik di Kota Malang adalah faktor sosial (10\%), faktor personal (14\%), faktor psikologi (19\%), faktor kultural (5\%), dan faktor lain-lain (52\%). Faktor lainlain sebagian besar karena faktor agama. Dua penelitian ini mengindikasikan bahwa komsumsi produk pangan organik didasari alasan kesehatan.

Permasalahan yang dihadapi oleh Kelompok Tani Sumber Urip-1 yang berada di Desa Wonorejo Kecamatan Poncokusumo Kabupaten Malang berangkat dari kendala penggunaan sitokinin yaitu suplai sitokinin kadang-kadang tidak lancar dan harganya mahal. Padahal di Desa Wonorejo terdapat potensi hayati yang dapat digunakan bahan pembuatan sitokinin organik, misalnya daun sirih, jahe, bawang putih, kunir, kencur, daun cengkeh, bunga kertas, bunga bougenville, dan lain sebagainya.

Secara spesifik setelah dilakukan diskusi/musyawarah dengan mitra, maka permasalahan mitra secara konkret dan menjadi prioritas yang harus ditangani adalah sebagai berikut: (1) Mitra tidak menguasai metode pembuatan sitokinin organik berbasis pada potensi lokal, dan (2) Mitra tidak menguasai metode penggunaan sitokinin organik sesuai bahan baku lokal.

\section{METODE}

Mitra dalam pendampingan ini adalah Kelompok Tani Sumber Urip-1 berada di Desa Wonorejo Kecamatan Poncokusumo Kabupaten Malang Propinsi Jawa Timur. Pendampingan dilakukan selama 6 bulan. Setelah dilakukan diskusi/ musyawarah dengan mitra, maka solusi permasalah mitra secara konkret dan menjadi prioritas yang harus ditangani adalah sebagai berikut (Tabel 1).

Tabel 1. Solusi permasalahan mitra

\begin{tabular}{|c|c|c|c|c|c|}
\hline No & Permasalahan & $\begin{array}{c}\text { Kegiatan Solusi } \\
\text { Permasalahan } \\
\text { (Metode yang } \\
\text { Digunakan) } \\
\end{array}$ & $\begin{array}{l}\text { Partisipasi Mitra } \\
\text { dalam Kegiatan }\end{array}$ & $\begin{array}{l}\text { Alat Bahan yang } \\
\text { Dibutuhkan }\end{array}$ & $\begin{array}{c}\text { Waktu } \\
\text { Kegiatan }\end{array}$ \\
\hline 1 & $\begin{array}{l}\text { Mitra tidak } \\
\text { menguasai } \\
\text { metode } \\
\text { pembuatan } \\
\text { sitokinin } \\
\text { organik }\end{array}$ & $\begin{array}{l}\text { Pelatihan dan } \\
\text { pendampingan } \\
\text { pembuatan } \\
\text { sitokinin } \\
\text { organik dari } \\
\text { bahan lokal }\end{array}$ & $\begin{array}{l}\text { Berperan aktif } \\
\text { dalam penyiapan } \\
\text { alat/bahan } \\
\text { Berperan aktif } \\
\text { sebagai peserta } \\
\text { pelatihan dan } \\
\text { pendampingan }\end{array}$ & $\begin{array}{l}\text { Blender, jurigen } \\
10 \mathrm{lt}, 1 \mathrm{~kg} \\
\text { bonggol pisang / } \\
\text { jangung muda, } 1 \\
\text { lt air kelapa, } 100 \\
\text { ml tetes tebu, dan } \\
\text { EM-4: } 5 \mathrm{ml} \text {. }\end{array}$ & 4 Bulan \\
\hline 2 & $\begin{array}{l}\text { Mitra tidak } \\
\text { menguasai } \\
\text { metode } \\
\text { penggunaan } \\
\text { sitokinin }\end{array}$ & $\begin{array}{l}\text { Pelatihan dan } \\
\text { pendampingan } \\
\text { penggunaan } \\
\text { sitokinin } \\
\text { organik }\end{array}$ & $\begin{array}{l}\text { Berperan aktif } \\
\text { dalam penyiapan } \\
\text { alat/bahan } \\
\text { Berperan aktif } \\
\text { sebagai peserta }\end{array}$ & $\begin{array}{l}\text { Sprayer } 15 \mathrm{lt} \text {, } \\
\text { pengaduk, dan } \\
\text { sitokinin organik. }\end{array}$ & 2 Bulan \\
\hline
\end{tabular}


organik

pelatihan dan

pendampingan

Catatan: Tiap-tiap jenis pelatihan menggunakan pola ToT (Training of Trainer) yang diikuti oleh 5 orang petani dari perwakilan Kelompok Tani Sumber Urip-1.

Pelatihan pembuatan dan pengunaan sitokinin organik dari bahan lokal adalah sebagai berikut (Tabel 2).

Tabel 2. Pelatihan dan Pelatihan Pembuatan dan Pengunaan Sitokinin Organik dari Bahan Lokal

\begin{tabular}{|c|c|c|c|}
\hline & $\begin{array}{c}\text { Pelatihan dan } \\
\text { Pelatihan } \\
\text { Pembuatan } \\
\text { Sitokinn } \\
\text { Organik } \\
\end{array}$ & $\begin{array}{c}\text { Pelatihan dan } \\
\text { Pelatihan } \\
\text { Penggunaan } \\
\text { Sitokinn Organik }\end{array}$ & $\begin{array}{c}\text { Desemias Pembuatan dan } \\
\text { Penggunaan Sitokinn } \\
\text { Organik }\end{array}$ \\
\hline Peserta & $\begin{array}{l}5 \text { orang anggota } \\
\text { Kelompok Tani } \\
\text { Sumber Urip-1 } \\
\text { Desa Wonorejo } \\
\text { Kecamatan } \\
\text { Poncokusumo } \\
\text { Kabupaten } \\
\text { Malang }\end{array}$ & $\begin{array}{l}5 \text { orang anggota } \\
\text { Kelompok Tani } \\
\text { Sumber Urip-1 Desa } \\
\text { Wonorejo } \\
\text { Kecamatan } \\
\text { Poncokusumo } \\
\text { Kabupaten Malang }\end{array}$ & $\begin{array}{l}10 \text { orang anggota Kelompok } \\
\text { Tani Sumber Urip-1 Desa } \\
\text { Wonorejo Kecamatan } \\
\text { Poncokusumo Kabupaten } \\
\text { Malang }\end{array}$ \\
\hline Fasilitator & Tim Pengabdi & Tim Pengabdi & Tim Pengabdi \\
\hline Co-Fasilitator & $\begin{array}{l}\text { Mahasiswa FKIP- } \\
\text { Biologi UMM. }\end{array}$ & $\begin{array}{l}\text { Mahasiswa FKIP- } \\
\text { Biologi UMM. }\end{array}$ & $\begin{array}{l}\text { Mahasiswa FKIP-Biologi } \\
\text { UMM. }\end{array}$ \\
\hline Tempat & $\begin{array}{l}\text { Rumah Ketua } \\
\text { Kelompok Tani } \\
\text { Sumber Urip I }\end{array}$ & $\begin{array}{l}\text { Lahan Kelompok } \\
\text { Tani Sumber Urip I }\end{array}$ & $\begin{array}{l}\text { Rumah Ketua Kelompok } \\
\text { Tani Sumber Urip I }\end{array}$ \\
\hline Waktu & 4 Bulan & 2 Bulan & $\begin{array}{l}1 \text { hari } \\
\text { Good Practice Pelatihan dan }\end{array}$ \\
\hline Materi & $\begin{array}{l}\text { Cara Pembuatan } \\
\text { Sitokinin Organik }\end{array}$ & $\begin{array}{l}\text { Cara Penggunaan } \\
\text { Sitokinin Organik }\end{array}$ & $\begin{array}{l}\text { Pendampingan Pembuatan, } \\
\text { Penggunaan, Packaging, } \\
\text { Labeling Sitokinin Organik }\end{array}$ \\
\hline Metode & $\begin{array}{l}\text { Fasilitator } \\
\text { menjelaskan dan } \\
\text { mempraktekan } \\
\text { cara pembuatan } \\
\text { sitokinin . } \\
\text { Fasilitator } \\
\text { mendampingi } \\
\text { pembuatan } \\
\text { sitokinin organik. }\end{array}$ & $\begin{array}{l}\text { Fasilitator } \\
\text { menjelaskan dan } \\
\text { mempraktekan cara } \\
\text { penggunaan } \\
\text { sitokinin. } \\
\text { Fasilitator } \\
\text { mendampingi } \\
\text { penggunaan sitokinin } \\
\text { organik. }\end{array}$ & $\begin{array}{l}\text { Fasilitator menjelaskan Good } \\
\text { Practice Pelatihan dan } \\
\text { Pendampingan Pembuatan, } \\
\text { Penggunaan, Packaging, } \\
\text { Labeling Sitokinin Organik }\end{array}$ \\
\hline $\begin{array}{l}\text { Partisipasi } \\
\text { Mitra }\end{array}$ & $\begin{array}{l}\text { Berperan aktif } \\
\text { dalam penyiapan } \\
\text { alat, bahan, dan } \\
\text { lahan } \\
\text { Berperan aktif } \\
\text { dalam pembuatan } \\
\text { sitokinin organik }\end{array}$ & $\begin{array}{l}\text { Berperan aktif dalam } \\
\text { penyiapan alat, } \\
\text { bahan, dan lahan } \\
\text { Berperan aktif dalam } \\
\text { penggunaan sitokinin } \\
\text { organik }\end{array}$ & $\begin{array}{l}\text { Berperan aktif dalam } \\
\text { penyiapan alat, bahan, dan } \\
\text { lahan } \\
\text { Berperan aktif dalam } \\
\text { deseminasi sitokinin } \\
\text { organik }\end{array}$ \\
\hline Keberhasilan & $\begin{array}{l}5 \text { orang Mitra } \\
\text { PPMI memahami } \\
\text { dan dapat }\end{array}$ & $\begin{array}{l}5 \text { orang Mitra PPMI } \\
\text { memahami dan dapat } \\
\text { penggunaan sitokinin }\end{array}$ & $\begin{array}{l}10 \text { orang Mitra PPMI } \\
\text { memahami dan tertarik } \\
\text { mengimplementasikan good }\end{array}$ \\
\hline
\end{tabular}


memproduksi organik.

sitokinin organik. practice pelatihan dan

pendampingan pembuatan, penggunaan, packaging, dan labeling Sitokinin Organik.

Motode yang digunakan untuk mengukur keberhasilan (capaian) pendampingan adalah angket tertutup yang akan mengukur pengetahuan dan keterampilan pembuatan, penggunaan, packaging, dan labelling sitokinin organik. Sedangkan untuk mengukur feeback (umpan balik) pendampingan digunakan angket terbuka kesediaan adopsi teknologi hasil pendampingan.

Tim pelaksana kegiatan pendampingan kelompok Tani Sumber Urip-1 yang menghadapi masalah penyediaan sitokinin ini terdiri dari Dosen yang memiliki keahlian yang memadai dan telah berpengalaman dalam bidang pangan organik dari aspek hulu sampai dengan hilir. Ketua Tim merupakan dosen di Pendidikan Biologi FKIP UMM yang mengajar dan menekuni bidang pangan dan gizi. Studi S3 yang bersangkutan juga mengambil konsentrasi Ilmu Gizi di Program Pascasarjana Universitas Airlangga Surabaya. Ketua Tim juga telah banyak melakukan kegiatan pendampingan Tani Sumber Urip-1 di wilayah Kabupaten Malang.

Dalam upaya meningkatkan kinerja kegiatan pendampingan pembuatan dan penggunaan Sitokinin ini, maka telah disepakati dan dibangun sinergisme tim dalam bentuk pembagian kerja, pola kooperasi, pola kolaborasi, morning meeting pada hari jum'at setiap minggunya. Ketua tim bertugas menyusun job deskripsi kerja anggota tim dan mahasiswa yang selanjutnya dikaji dan disempurnakan dalam rapat koordinasi. Dalam tingkatan teknis disepakati Ketua Tim bertugas untuk menyiapkan bahan-bahan akademik, pengurusan ijin dan lobi program, serta mengkoordinasikan semua kegiatan.

Anggota Tim bertugas mengkoordinasikan penyiapan alat, bahan, sarana pendukung, serta membangun partisipasi masyarakat/kelompok, terlibat aktif dalam setiap kegiatan, melakukan monitoring dan evaluasi kegiatan. Dalam pelaksanaan kegiatan juga dibantu oleh 10 (sepuluh) mahasiswa yang sebelumnya terlebih dahulu diberi pembekalan. Di sisi lain secara bersama-sama (Ketua Tim, Anggota Tim, Mahasiswa, Ketua Kelompok Tani, dan Anggota Kelompok Tani) melakukan monitoring dan evaluasi sesuai dengan jadwal yang telah ditentukan. Hasil monitoring dan evaluasi tersebut selanjutnya digunakan landasan dalam upaya meningkatkan kinerja program yang kemudian diikuti dengan redesain program dan redistribusi tugas antara Ketua Tim, Anggota Tim, dan Mahasiswa.

\section{HASIL DAN PEMBAHASAN}

Hasil yang dicapai dalam kegiatan Pendampingan Pembuatan Sitokinin Organik di Kelompok Tani Sumber Urip-1 Desa Wonosari Kecamatan Poncokusumo Kabupaten Malang adalah sebagai berikut.

a. Pelatihan Pembuatan Sitokinin Organik dari Bahan Lokal (Tabel 3).

Tabel 3. Pelatihan Pembuatan Sitokinin Organik dari Bahan Lokal

\begin{tabular}{cll}
\hline Peserta & $:$ & \multicolumn{1}{c}{5 orang anggota Kelompok Tani Sumber Urip-1 Desa Wonorejo } \\
& Kecamatan Poncokusumo Kabupaten Malang \\
\hline & & DR.H.Moch. Agus Krisno B,M.Kes. \\
Fasilitator & Fendy Hadian Permana, S.Pd,M.Pd. & Dr. Lud Waluyo,M.Kes. \\
& Husamah, S.Pd., M.Pd. \\
& Tien Aminah, S.Kep, M.Kep. \\
Co-Fasilitator & $:$ 10 Mahasiswa FKIP-Biologi UMM. \\
Tempat & $:$ & Rumah Ketua Kelompok Tani Sumber Urip I \\
Waktu & $:$ & Januari 2018 s/d April 2018 (4 Bulan) \\
\hline
\end{tabular}




\begin{tabular}{cll}
\hline Materi & $:$ & Cara Pembuatan Sitokinin Organik \\
Metode & $:$ & Fasilitator menjelaskan dan mempraktekan cara pembuatan sitokinin \\
& Fasilitator mendampingi pembuatan sitokinin organik. \\
Partisipasi & $: \begin{array}{l}\text { Berperan aktif dalam penyiapan alat, bahan, dan lahan } \\
\text { Mitra }\end{array}$ & $\begin{array}{l}\text { Berperan aktif dalam pembuatan sitokinin organik } \\
\text { Kerang Mitra PPMI memahami dan dapat memproduksi sitokinin } \\
\text { Keberhasilan }\end{array}$ \\
\hline
\end{tabular}
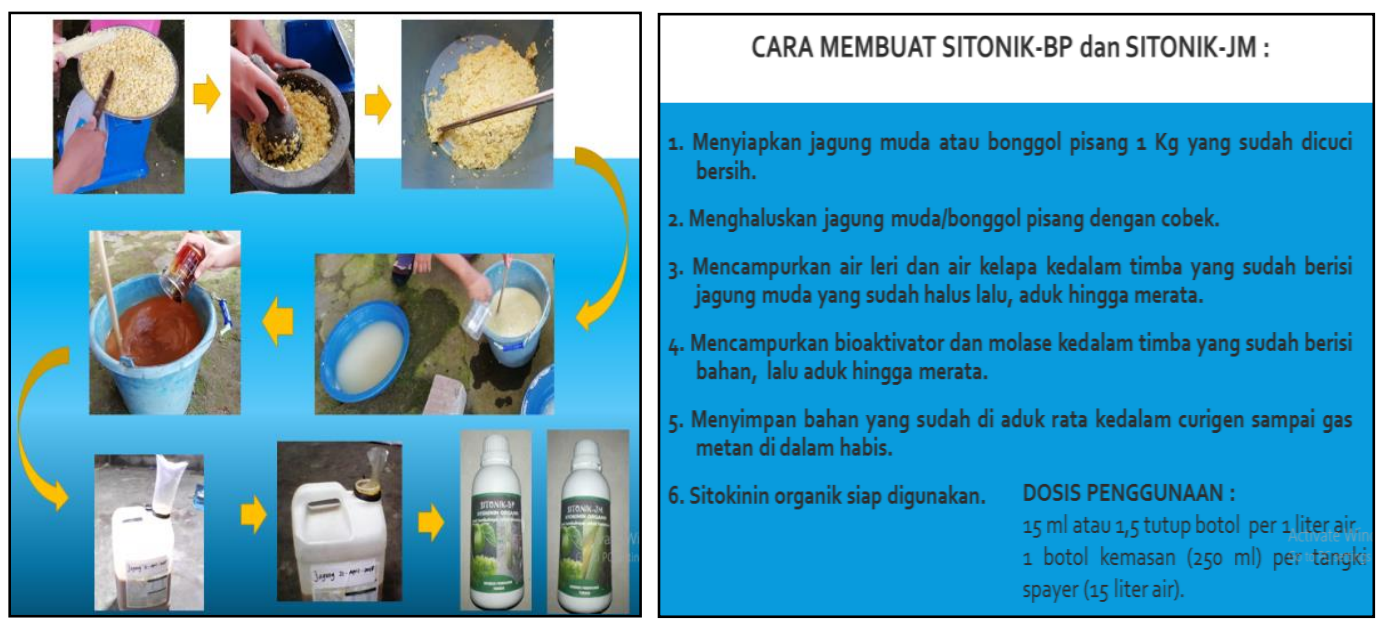

Gambar 1. Proses Pembuatan Sitokinin Organik"Sitonik-BP" (Sitokinin Organik dari Bonggol Pisang) dan "Sitonik-JM”(Sitokinin Organik dari Jagung Muda)

b. Pelatihan dan Pendampingan Penggunaan Sitokinin dari Bahan Lokal (Tabel 4)

Tabel 4. Pelatihan dan Pendampingan Penggunaan Sitokinin dari Bahan Lokal

\begin{tabular}{|c|c|}
\hline Peserta & $\begin{array}{l}5 \text { orang anggota Kelompok Tani Sumber Urip-1 Desa Wonorejo } \\
\text { Kecamatan Poncokusumo Kabupaten Malang }\end{array}$ \\
\hline Fasilitator & $\begin{array}{l}\text { Dr.H.Moch. Agus Krisno B,M.Kes. } \\
\text { Fendy Hadian Permana, S.Pd,M.Pd. } \\
\text { : Dr. Lud Waluyo,M.Kes. } \\
\text { Husamah, S.Pd., M.Pd. } \\
\text { Tien Aminah, S.Kep, M.Kep. }\end{array}$ \\
\hline Co-Fasilitator & : 10 Mahasiswa FKIP-Biologi UMM. \\
\hline Tempat & : Lahan Kelompok Tani Sumber Urip I \\
\hline Waktu & : $\quad$ Mei 2018 s/d Juni 2018 (2 Bulan) \\
\hline Materi & : Cara Menggunakan Sitokinin Organik \\
\hline Metode & $\begin{array}{l}\text { Fasilitator menjelaskan dan mempraktekan cara penggunaan sitokinin } \\
\text { Fasilitator mendampingi penggunaan sitokinin organik. }\end{array}$ \\
\hline Partisipasi & . Berperan aktif dalam penyiapan alat, bahan, dan lahan \\
\hline Mitra & : Berperan aktif dalam pengunaan sitokinin organik \\
\hline Keberhasilan & $\begin{array}{l}5 \text { orang Mitra PPMI memahami dan dapat menggunakan sitokinin } \\
\text { organik. }\end{array}$ \\
\hline
\end{tabular}




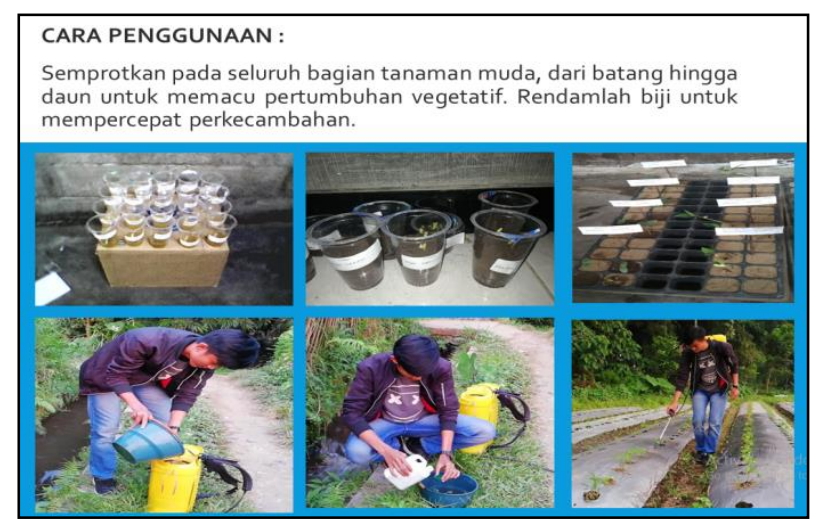

Gambar 2. Proses Pengunaan Sitokinin Organik "Sitonik-BP" (Sitokinin Organik dari Bonggol Pisang) dan "Sitonik-JM" (Sitokinin Organik dari Jagung Muda) pada Biji dan Tanaman Mentimun

C. Diseminasi Best Practice / Goods Practice Pembuatan dan Penggunaan Sitokinin Organik dari Bahan Lokal (Tabel 5)

Tabel 5. Deseminasi Best Practice / Goods Practice Pembuatan dan Penggunaan Sitokinin Organik dari Bahan Lokal

\begin{tabular}{|c|c|}
\hline Peserta & $\begin{array}{l}10 \text { orang anggota Kelompok Tani Sumber Urip-1 Desa Wonorejo } \\
\text { Kecamatan Poncokusumo Kabupaten Malang }\end{array}$ \\
\hline Fasilitator & $\begin{array}{l}\text { Dr.H.Moch. Agus Krisno B,M.Kes. } \\
\text { Fendy Hadian Permana, S.Pd,M.Pd. } \\
\text { : Dr. Lud Waluyo,M.Kes. } \\
\text { Husamah, S.Pd., M.Pd. } \\
\text { Tien Aminah, S.Kep, M.Kep. }\end{array}$ \\
\hline Co-Fasilitator & : 10 Mahasiswa FKIP-Biologi UMM. \\
\hline Tempat & : Rumah Ketua Kelompok Tani Sumber Urip I \\
\hline W & $\begin{array}{l}\text { : } 10 \text { Mei } 2018 \\
\text { : Good Practice Pelatihan dan Pendampingan Pembuatan, Pe }\end{array}$ \\
\hline $\mathrm{Me}$ & $\begin{array}{l}\text { Packaging, Labeling Sitokinin Organik. } \\
\text { Fasilitator menjelaskan good practice pelatihan dan pendampingan } \\
\text { pembuatan, penggunaan, packaging, dan labeling Sitokinin Organik. }\end{array}$ \\
\hline Partisipa & Berperan aktif dalam penyiapan tempat, fasilitas pendukung \\
\hline Mitra & aktif sebagai peserta deseminasi \\
\hline Keberl & $\begin{array}{l}10 \text { orang Mitra PPMI memahami dan tertarik mengimplementasikan } \\
\text { good practice pelatihan dan pendampingan pembuatan, penggunaan, } \\
\text { packaging, dan labeling Sitokinin Organik. }\end{array}$ \\
\hline
\end{tabular}

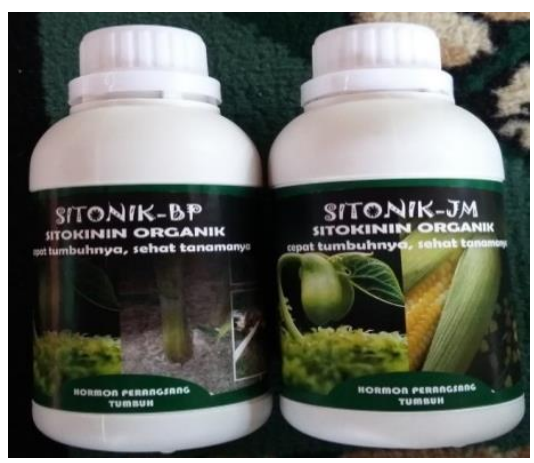

Gambar 3. Produk Sitokinin Organik "Sitonik-BP” (Sitokinin Organik dari Bonggol Pisang) dan "Sitonik-JM" (Sitokinin Organik dari Jagung Muda) 


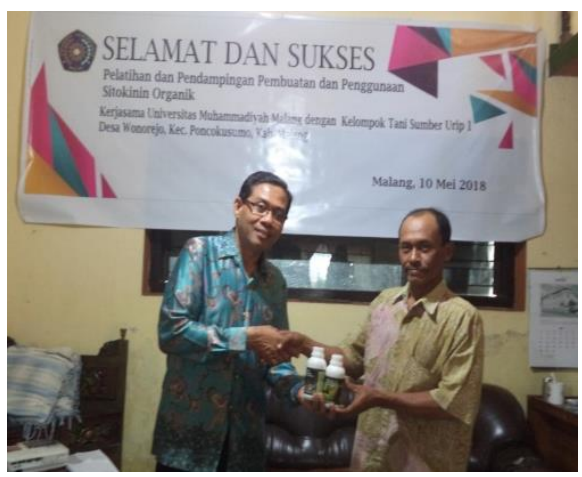

Gambar 4. Penyerahan Produk Sitokinin Organik ke Ketua Kelompok Tani Sumber Urip-1

Dari ketiga kegiatan tersebut di atas dapat dinyatakan bahwa hasil pendampingan tergolong sangat baik. Pada pelatihan pendampingan pembuatan sitokinin organik 5 anggota Kelompok Tani Sumber Urip-1 (100\%) memahami dan dapat memproduksi sitokinin organik. Pada pelatihan pendampingan penggunaan sitokiin organik 5 anggota Kelompok Tani Sumber Urip-1 (100\%) memahami dan dapat menggunakan sitokinin organik. Pada deseminasibest practice pembuatan, penggunaan, packaging, dan labellng sitokiin organik 10 anggota Kelompok Tani Sumber Urip-1 (100\%) memahami dan dapat melakukan pembuatan, penggunaan, packaging, dan labellng sitokinin organik. Keberhasilan pendampingan inilah yang mendorong mitra melakukan adopsi teknologi yang dihasilkan dalam program pendampingan. Dampak pendampingan ini adalah Kelompok Tani Sumber Urip-1 dapat dapat melakukan pembuatan, penggunaan, packaging, dan labellng sitokinin organik yang dapat dikembangkan sebagai kegiatan produktif yang bernilai ekonomi di masa mendatang.

Di sisi lain setiap tanaman membutuhkan hormon tumbuh, termasuk sitokinin. Menuut Sitompul dan Guritno (2008) setiap tumbuhan memiliki struktur dan morfologi tentunya, hal tersebut terjadi karena dipengaruhi oleh faktor intrasel yang ada dalam gen sebagai bentuk dalam pembawa sifat atau dikenal dengan faktor hereditas. Selain dari faktor intrasel, dikenal juga faktor intersel yang berupa zat tumbuh yang disebut dengan hormon tumbuh yang ada pada tumbuh-tumbuhan. Hormon-hormon tumbuhan tersebutlah yang mengatur arah dan kecepatan, kapan tumbuhan berbunga, buah akan masak, kapan daun akan gugur. Hormon tumbuh adalah senyawa kimia yang sangat aktif. Hormon yang memengaruhi pertumbuhan sehingga sering disebut hormon zat tumbuh. Hormon tumbuh pada tumbuhan ditemukan oleh ahli botani yang berasal dari belanda yang bernama Went, tahun 1926 . Hormon tumbuh tumbuhan memiliki banyak jenis. Hormon tumbuhan adalah auksin, giberelin, sitokinin, gas etilen dan asam absisat serta kalin.

Menurut Ihsan (2016) hormon sitokinin berperan penting dalam merangsang pembelahan sel tumbuhan. Sitokonin berasal dari kata cytokinin yang berarti terkait dengan pembelahan sel. Senyawa dari hormon sitokinin yang pertama kali ditemukan adalah kinetin. Pada awalnya, kinetin diperoleh dari ekstrak sperma burung bangkai, namun kemudian diketahui bahwa kinetin juga bisa ditemukan pada manusia dan tumbuhan. Selain kinetin, senyawa lain yang dapat berfungsi sebagai hormon sitokinin adalah zeatin. Zeatin bisa diperoleh dari ekstrak biji jagung yang masih muda. Kemudian pada perkembangan berikutnya, zeatin juga diketahui sebagai komponen aktif utama pada air kelapa. Dengan demikian, air kelapa juga memiliki kemampuan untuk merangsang pembelahan sel. Sitokinin alami lain misalnya adalah 2iP. Sitokinin alami merupakan turunan dari purin. Sitokinin sintetik kebanyakan dibuat dari turunan purin pula, seperti N6-benziladenin (N6-BA) dan 6benzilamino-9-(2-tetrahidropiranil-9H-purin) (PBA). Fungsi sitokinin bagi pertumbuhan tanaman adalah (1) Memacu pertumbuhan dan perkembangan tumbuhan dengan merangsang proses pembelahan dan pembesaran sel; (2) Merangsang perkecambahan dengan memecah 
fase dormansi pada biji, sehingga pertumbuhan bibit dapat berlangsung dengan cepat; (3) Memacu pertumbuhan tunas-tunas baru; (4) Hormon sitokinin dapat menunda penuaan pada hasil panen, sehingga daya tahan hasil panen lebih lama; (5) Menaikkan tingkat mobilitas unsur-unsur dalam tumbuhan; dan (6) Sintesis pembentukan protein akan meningkat dengan pemberian hormon sitokinin.

Menurut Lestari (2016) beberapa bahan alami yang dapat digunakan sebagai bahan sitokinin organik adalah bonggol pisang, jagung muda, bekicot, tetes tebu, dan air kelapa. Bahan pembuatan sitokinin organik adalah: $1 \mathrm{~kg}$ bonggol pisang/1 kg jagung muda, $1 \mathrm{lt}$ air kelapa, $100 \mathrm{ml}$ tetes tebu/ 1 ons gula merah/ 1 ons gula pasir, dan agen fermentasi: $5 \mathrm{ml}$ (1 tutup botol) EM-4/ 0,5 ons tape / $100 \mathrm{ml}$ Mol bonggol pisang. Sedangkan cara pembuatanya adalah: bonggol pisang / bulir jagung muda diblender, campur dan aduk semua bahan secara merata, masukkan semua bahan dalam wadah (jerigen) kemudian tutup dengan rapat, dan simpan selama 14 hari pada tempat yang teduh, setiap hari tutup jerigen dibuka untuk membuang gas yang dihasilkan dalam fermentasi.

Menurut Septari (2014) ekstrak tanaman dari bonggol pisang mengandung hormon sitokinin dan rebung yang mengandung hormon giberelin. Pemberian ekstrak tanaman bertujuan untuk memacu pertumbuhan serta perkembangan tanaman. Sedangkan jagung muda adalah bahan alami yang mengandung yang mengandung sitokinin sehingga yang membantu dalam pertumbuhan kultur.

Menurut Lestari (2016) cara menggunakan sitokinin adalah sebagai berikut: 1)Buat larutan sitokinin dengan dosis $15 \mathrm{ml}$ (3 tutup botol) sitokinin organik dicampur dengan 1 liter air bersih, 2) Untuk tujuan meransang perkecambahan dengan memecah fase dormansi pada biji, maka lakukan perendeman di biji tersebut di larutan sitokinin, 3) Untuk tujuan memacu pertumbuhan tunas-tunas baru, semprotkan secara metara (samapai basah) ke tunas yang dikehendaki (tunas akar, tunas cabang batang, tunas daun. Bisa juga disemprotkan pada permukaan tanah untuk memperbanyak tunas bawang merah maupun bawang putih, Disemprotkan pada batang dan daun untuk memperbanyak tunas batang dan daun cabai.

Menurut Budiyanto (2018) proses pembuatan sitokinin organik Sitonik-BP" (Sitokinin Organik dari Bonggol Pisang) dan "Sitonik-JM" (Sitokinin Organik dari Jagung Muda) adalah (1) Menyiapkan jagung muda atau bonggol pisang $1 \mathrm{Kg}$ yang sudah dicuci bersih; (2) Menghaluskan jagung muda/bonggol pisang dengan cobek; (3) Mencampurkan air leri dan air kelapa kedalam timba yang sudah berisi jagung muda yang sudah halus lalu, aduk hingga merata; (4) Mencampurkan bioaktivator dan molase kedalam timba yang sudah berisi bahan lalu, aduk hingga merata; (5) Menyimpan bahan yang sudah di aduk rata kedalam curigen sampai gas metan di dalam habis; dan (6) Sitokinin organik siap digunakan.

Hasil uji coba sitokinin organik Sitonik-BP” (Sitokinin Organik dari Bonggol Pisang) dan "Sitonik-JM" (Sitokinin Organik dari Jagung Muda) selama satu minggu menunjukkan bahwa Biji Ketimun (Cucumis sativus) yang diberi perlakuan sitokinin organik memiliki indeks pertumbuhan lebih cepat dibandingkan tanaman yang tidak menggunakan sitokinin organik, hal ini berarti sistem kerja pada tanaman sitokinin organik lebih cepat tumbuh mulai dari tahap perendaman biji, sedangkan pada tanaman non sitokinin pertumbuhannya tidak secepat tanaman sitokinin organik karena pada fase dormansi tidak berjalan dengan sempurna (Budiyanto, 2018).

Menurut Budiyanto (2018) penggunaan sitokinin organik Sitonik-BP" (Sitokinin Organik dari Bonggol Pisang) dan "Sitonik-JM" (Sitokinin Organik dari Jagung Muda) dilakukan dengan cara menyemprotkan pada seluruh bagian tanaman muda, dari batang hingga daun untuk memacu pertumbuhan vegetatif dengan dosis $15 \mathrm{ml}$ atau 1,5 tutup botol per 1 liter air. Adapun 1 botol kemasan $(250 \mathrm{ml})$ per tangki spayer (15 liter air). 


\section{KESIMPULAN}

Kesimpulan yang dapat diberikan adalah (1) Melalui serangkaian kegiatan pelatihan, dan pendampingan pembuatan dan penggunaan sitokinin organik di Kelompok Tani Sumber Urip-1 Desa Wonosari Kecamatan Poncokusumo Kabupaten Malang, maka mitra PPMI telah menguasai, (a) Metode pembuatan sitokinin organik dan (b) Metode penggunaan sitokinin organik. (2) Produk sitokinin diberi merk "Sitonik-BP" (Sitokinin Organik dari Bonggol Pisang) dan "Sitonik-JM" (Sitokinin Organik dari Jagung Muda).

\section{SARAN}

Berdasarkan hasil kegiatan pelatihan, dan pendampingan pembuatan dan penggunaan sitokinin di Kelompok Tani Sumber Urip-1 Desa Wonosari Kecamatan Poncokusumo Kabupaten Malang, maka dalam upaya lebih mengoptimalkan kemanfaatan program untuk mitra dapat disarankan untuk segera melakukan: (1) Pendampingan pemasaran sitokinin dari bahan lokal melalui jejaring sosial (FB dan Twitter), pedagang tanaman hias dan kelompok tani organik dan (2) Perancangan dan pendampingan analisis ekonomi produksi sitokinin organik.

\section{DAFTAR PUSTAKA}

Aertsens, J., Verbeke, W., Mondelaers, K., \& van Huylenbroeck, G. (2009). Personal determinants of organic food consumption: A review. British Food Journal, 111(10), 1140-1167. doi: https://doi.org/10.1108/00070700910992961

Budiyanto, M. A. K. (2007). Persepsi masyarakat tentang pertanian hortikultura organik di Kabupaten Malang. Laporan Penelitian, Malang: Universitas Muhammadiyah Malang.

Budiyanto, M. A. K. (2013). Model pengembangan produksi pangan organik. Laporan Penelitian, Malang: Universitas Muhammadiyah Malang.

Budiyanto, M. A. K. (2018). Cara pembuatan sitokinin organik. Makalah, Malang: Universitas Muhammadiyah Malang.

Budiyanto, M. A. K., Rahardjanto, A., \& Waluyo, L. (2020a). Mastery of Sumber Urip-1 farmer group in Malang Regency in the production and application of organic auxins and gibberellins. Journal of Community Service and Empowerment, 1(2), 64-72. doi: https://doi.org/10.22219/jcse.v1i2.12259.

Budiyanto, M. A. K., Waluyo, L., \& Rahardjanto, A. (2020b). Pembuatan akarisida organik di kelompok tani Sumber Urip-1 Desa Wonorejo Kecamatan Poncokusumo Kabupaten Malang. International Journal of Community Service Learning, 4(1), 10-16.

Insan, H. F. (2016). Hormon tumbuhan atau ZPT (Zat Pengatur Tumbuh). Retrieved from https://www.facebook.com/notes/frederich-h-fajar-insanmardeka-theysen/hormontumbuhan-atau-zpt-zat-pengatur-tumbuh/10154553693703714/.

Jolly, D. A., \& Norris, K. (1991). Marketing prospects for organic and pesticide-free produce. American Journal of Alternative Agriculture, 6(4), 174-179.

Lestari, T, (2016). Teknologi pembuatan dan aplikasi zat pengatur tumbuh (ZPT). Retrieved from https://pekalongankab.go.id/informasi/artikel/pertanian/8639-teknologipembuatan-dan-aplikasi-zat-pengatur-tumbuh-zpt.html.

Prihandarini, R. (2009). Potensi pengembangan pertanian organik. Departemen Pertanian, Sekjen Maporina.

Septari, Y., Nelvia, N. \& Amri, A. I. (2013). Pengaruh pemberian beberapa jenis ekstrak tanaman sebagai ZPT dan rasio amelioran terhadap pertumbuhan dan produksi padi varietas Inpari 12 di lahan gambut. Jurnal Online Mahasiswa Fakultas Pertanian, 1(1), $1-9$.

Sitompul, S. M., \& Guritno, B. (2008). Analisis pertumbuhan tanaman. Gadjah Mada Universitas Press. 